\title{
Fertile soil or no man's land: cooperation and conflict in the placental bed
}

\section{Citation}

Haig, David. 2010. Fertile soil or no man's land: cooperation and conflict in the placental bed. In Placental Bed Disorders Basic Science and its Translation to Obstetrics, eds. by Robert Pjnenborg, Ivo Brosens, and Roberto Romero, 165-173. Cambridge: Cambridge University Press.

\section{Published Version}

doi:10.1017/CB09780511750847.017

\section{Permanent link}

http://nrs.harvard.edu/urn-3:HUL.InstRepos:32970058

\section{Terms of Use}

This article was downloaded from Harvard University's DASH repository, and is made available under the terms and conditions applicable to Other Posted Material, as set forth at http:// nrs.harvard.edu/urn-3:HUL.InstRepos:dash.current.terms-of-use\#LAA

\section{Share Your Story}

The Harvard community has made this article openly available.

Please share how this access benefits you. Submit a story.

Accessibility 


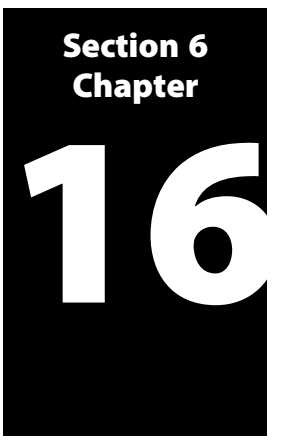

\title{
Genetics
}

\section{Fertile soil or no man's land: cooperation and conflict in the placental bed}

\author{
David Haig
}

Department of Organismic and Evolutionary Biology, Harvard University, Cambridge, MA, USA

\section{Introduction}

In 1910, Gräfenberg wrote that ideas about relations between the human ovum and ovum bed [Eibett] had undergone a dramatic change during the previous decade. The ovum was no longer viewed as a passive object around which maternal tissues spread a protective cover. Far from being a helpless germ in need of protection, the ovum was a cheeky intruder [ein frecher Eindringling] that eats its way deep into the uterine mucosa. A popular comparison had been of the villi sinking into the endometrium as the roots of a tree sink into the earth, but Gräfenberg saw a hint of antagonism between the roots of the ovum and the surrounding soil. In his opinion, various structural and enzymatic features of the decidua were defensive reactions against the destructive ovum [1]. (I have translated the German $E i$ (egg) as ovum, the term used in the contemporary English literature. We would now call the 'ovum' an embryo.)

Grosser took a contrary view. Gräfenberg should not have taken Roux's 'struggle of parts within the organism' quite so literally. The primary function of the decidua was obvious; to act as a fertile soil [Nährboden] for supporting growth of the ovum. Toward this end, trophoblast and decidua formed an effective mutually coordinated, or better preservational, system in which one partner could not attack the other, nor the other defend itself, in opposition to what was imperative for the survival of the species [2: 289-290]. (Nährboden can be translated as fertile soil or as culture medium.)

My subject is the tension between hostile and amicable accounts of maternal-embryo relations; between a cooperative view, in which mother and embryo engage in mutual action in pursuit of common goals, and a conflictual view, in which mother and embryo have antagonistic goals and act at crosspurposes. This chapter has three parts. In the first part, I present a partial history of ideas about the maternal-fetal boundary of the gravid human uterus. It is a partial history in the dual sense of not complete and not impartial. A complete history would require a book-length exposition and fluency in multiple European languages but, in the space allotted, I can achieve no more than a sketch. My time span is from the late eighteenth century to the period between the World Wars. My exposition is not impartial because I discuss an idiosyncratic set of papers that appeal to me because of the images and metaphors employed to describe maternal-fetal relations. In the second part, I discuss the modern theoretical understanding of parent-offspring relations and how this predicts a complex interplay of cooperation and conflict. In the final part, I consider how this interplay is expressed in relations between the endometrium and early human embryos.

\section{Mixed metaphors: historical interpretations of the maternal-fetal interface}

Fundamental progress in understanding the maternal-fetal interface occurred in the brief 5 -year period from 1895 to 1899 . Before this period, there was considerable confusion about which cell types were fetal and which were maternal. Strange theories, from a modern perspective, were expounded (e.g. the chorion was a maternal tissue deposited around the ovum as it traversed the Fallopian tube, analogous to the white of a hen egg [3]). After this period, descriptions of the maternal-fetal interface are readily intelligible to a modern reader, although many details still remained to be elucidated. My account will race through the nineteenth century, outline the discoveries that caused this change in perspective, and then discuss early reactions to the realization that human embryos 'invaded' maternal tissues. 
About the month of May 1754, John Hunter was called in to examine the uterus, with placenta in situ, of a woman who had died undelivered at full term. A colleague had previously injected red wax into the uterine arteries and yellow wax into the uterine veins. 'Upon cutting into the placenta [Hunter] discovered in many places of its substance, yellow injection; in others red, and in many others these two colours intermixed. This substance of the placenta, now filled with injection, had nothing of the vascular appearance, nor that of extravasation, but had a regularity in its form which showed it to be a natural cellular structure, fitted to be a reservoir for blood' [4]. ('Cellular structure' refers to the cavernous spaces of the placenta; beware of changes in meaning!)

The fetus, by contrast, had: 'a communication with the placenta of another kind. The arteries from the foetus pass out to a considerable length, under the name of the umbilical chord, and when they arrive at the placenta, ramify upon its surface, sending into its substance branches which pass through it, and divide into smaller and smaller, till at last they terminate in veins; these uniting, become larger and larger, and end in one, which at last terminates in the proper circulation of the foetus' [4].

Thus, Hunter had arrived at an essentially correct view of the maternal and fetal circulations in the term placenta: maternal blood passed out of the mother's circulation into the spongy substance of the placenta a structure Hunter viewed as of solely fetal origin before returning to the general maternal circulation. At no time was there admixture of maternal and fetal blood. Much of the nineteenth century involved controversy between Hunterians who accepted this view of placental blood flow and non-Hunterians who believed that maternal blood did not enter the placenta and that the Hunterian theory was based on experimental artifacts $[5,6]$. By the end of the century, the Hunterian view was predominant.

The precise nature of the covering of the tufts (villi) that projected into the cellular structure of the placenta was also controversial. Reid proposed an influential, but incorrect, resolution of this problem: 'when the blood of the mother flows into the placenta through the curling arteries of the uterus, it passes into a large sac formed by the inner coat of the vascular system of the mother, which is intersected in many thousands of different directions, by the placental tufts projecting into it like fringes, and pushing its thin wall before them in the form of sheaths, which closely envelope both the trunk and each individual branch composing these tufts. From this sac the maternal blood is returned by the utero-placental veins without having been extravasated, or without having left her own system of vessels' [7].

By the 1880s, advances in microscopical techniques had enabled a more accurate view of the villous sheath. Villi were now seen as covered by two layers: an outer syncytial layer and an inner cellular layer (Langhans' cells) adjacent to the mesenchymal core of the villus. There was great confusion, however, about the nature and origin of these layers (a review of the many hypotheses is beyond the scope of this chapter). Marchand made a crucial advance in 1895 when he recognized that 'decidual' tumors (choriocarcinomas of modern parlance) were composed of the same cellular elements as the villous sheath. At first, Marchand interpreted the sheath as a symbiosis between the syncytium, derived from the uterine (or tubal) epithelium, and ectodermal cells of fetal origin, but he soon recognized that both layers were fetal $[8,9]$. He now suggested that chorionepithelioma was the most appropriate name for these tumors.

In June 1897, Hubert Peters presented a very early human embryo at the Congress of the German Gynecological Society in Leipzig. This embryo had been found at autopsy of a young woman who had killed herself 3 days after a missed menstrual period. Peters' subsequent monograph described the embryo in detail, together with observations of the Umlagerungszone, a confusing region in which maternal and fetal cells were jumbled together amidst cellular debris. Peters' preparations made clear that the embryo had sunk into, and embedded itself within, the uterine mucosa (previous hypotheses had viewed the decidua as growing up and enveloping the embryo) and that the syncytium was of fetal origin [10]. (The original meaning of Umlagerungszone seems to have been a zone of transformation, see discussion by Grosser who preferred instead Durchdringungszone (penetration-zone) [2; 306-307].)

Prior to the late 1890 s, the human embryo was not generally perceived as invading maternal tissues. The concept of trophoblastic invasion developed from an appreciation of the great destructive power of chorionepitheliomas; from the description of Peters' ovum embedded within the uterine mucosa; and from comparative studies of implantation in hedgehogs, rodents, and rabbits. After this change in outlook, the search for the maternal-fetal boundary shifted 
outward (to adopt the fetal perspective) from the lining of the chorionic villi into the Umlagerungszone. By the time that Teacher reviewed the literature on chorionepitheliomas in 1903, there was an emerging consensus that the syncytium was derived from fetal Langhans' cells and that the human embryo digested its way into the uterine lining (although some continued to defend older interpretations) [11].

Once trophoblast was recognized as invading maternal tissues, it was a small step (taken by several authors) to view the process of implantation as a conflict between maternal and fetal tissues, with the decidua functioning as a protective bulwark against intrusion by trophoblast $[12,13,14,15,16]$. Polano wrote of an antagonism between maternal tissues and the motherforeign tissues of the child, and described the latter as establishing outposts in enemy territory (Vorposten in Feindesland) [14]. In an authoritative review, published in 1910, Grosser claimed that most authors saw the formation of the decidua as 'a provision against the too intensive penetration of the ovum into the mucous membrane', but himself favored the alternative hypothesis that decidual cells functioned as a store of nutrients for use by the embryo [17: 139-140].

Gräfenberg applied bacteriological methods to investigate the respective roles of ovum and decidua in nidation. He prepared homogenates from firsttrimester human placentas and showed that these contained a proteolytic activity that eroded proteincontaining culture media. This activity was absent in placental homogenates from the second half of pregnancy. The proteolytic activity, however, was attenuated when placental homogenates were mixed with decidual homogenates, especially those prepared from first-trimester decidua. Therefore, Gräfenberg concluded the decidua produced antitryptic ferments (protease inhibitors) to act as a defense against the tryptic ferments (proteases) of the chorion. He suggested that Nitabuch's fibrinoid provided additional resistance, both mechanical and biochemical, to penetration by trophoblast [1]. For Linzenmeier, the ferments and antiferments described by Gräfenberg were the weapons (Waffen) used by fetal and maternal cells in their struggle (Kampf) in the contact zone [18].

On the eve of the conflagration that was to engulf Europe, Johnstone used eerily prescient language: 'The border zone ... is not a sharp line, for it is in truth the fighting line where the conflict between the maternal cells and the invading trophoderm takes place, and it is strewn with such of the dead on both sides as have not already been carried off the field'. Despite these images, Johnstone concluded that the decidual reaction was 'in all probability indirectly but equally protective to the embryo, in that, by supporting and strengthening the maternal capillaries, it prevents a too sudden and too extensive opening up of the vessels. ... The formation of the decidua is therefore to the mutual advantage of both mother and child' [19]. One could ascribe a defensive function to the decidua, employ militaristic metaphors, and yet view maternal-fetal relations as fundamentally harmonious.

Caffier extended Gräfenberg's experimental work on placental ferments after the Great War which provided him with a new metaphor for the maternal-fetal boundary: the fibrinoid layer of the border zone was a no man's land [Niemandsland] created by the reciprocal proteolytic actions of ovum and ovum bed. He suggested that abortion resulted from a preponderance of the proteolytic activity of the mother-soil [Mutterboden] whereas placenta accreta resulted from excess proteolytic activity of the embryo [20,21].

Kleine advanced similar views in his systematic pathology of the penetration zone, based on the modern perception that pregnancy was a biological struggle between maternal and fetal organisms. The decidua showed a defensive reaction against the attacks [Angriffe] of the trophoblast. Developmental abnormalities resulted from a mismatch between the aggressiveness of the fetal epithelium and the defensive powers of maternal tissues. Thus, overly strong defenses could result in an early abortion (by shutting off the embryo from the maternal blood supply) whereas weak defenses could result in the destructive infiltration of a chorionepithelioma. Kleine observed that a decidual reaction occurs exclusively in those mammals in which the trophoblast destroys the uterine mucosa, and interpreted this correlation as indirect evidence for antagonism between the decidua and trophoblast [22].

Where some saw 'a ruthless attack and an equally vigorous defense' others saw 'a nicely worked out cooperation to produce a definite harmonious end' [23]. For Mossman, the idea that the decidua functioned as a defensive bulwark was 'quite unsubstantiated'. It seemed more logical 'to assume that decidual tissue develops as a glycogen-storing tissue ... partly at least for the purpose of being invaded and absorbed by trophoblast, rather than to prevent such invasion.' [24: 168]. Here, Mossman referred to the principal 
hypothesis of those who viewed implantation as a cooperative process: decidual cells were provided by the mother as pabulum for nourishment of the embryo $[25,26]$. Bonnet saw the migration of leukocytes to the maternal-fetal border and their subsequent disintegration as a mechanism whereby the mother transported nutrients to the embryo [25]. (By contrast, Frassi interpreted the leukocytes as a means of halting the parasitic penetration of the ovum [13].)

None of the authors who described the maternalfetal boundary as a battleground offered wellarticulated reasons for why mother and offspring should be at war. Their use of military metaphors did not reflect strong theoretical preconceptions but was rather an attempt to make sense of what they saw through their microscopes. Undoubtedly, the images they chose to describe what they saw were shaped by the militaristic ethos of their age, but there were other strongly competing images of nurturing love of mothers for infants that could have been used if the histology had been different. After World War II, occasional descriptions can be found of the placental bed as a battleground or a no man's land but these passages lack the ferocity of the earlier period.

\section{Evolutionary conflict in parent-offspring relations}

Decidual reactions occur only in mammals with invasive placentation. This observation has been used to support different theories. McLaren interpreted the decidual reaction as evidence that the decidua functions as a barrier to trophoblast. 'If the decidual reaction were acting as a protective device, one would expect it to be more highly developed in those forms where mother and fetus are more intimately fused. The distribution of decidual development would thus seem to favor a protective rather than a nutritional role' [27]. But Robertson \& Warner used the same correlation to make the opposite inference: 'There must be significance in the fact that only in hemochorial placentation is there development of a true decidua ... It may therefore be concluded that decidua is essential for the success of hemochorial placentation and it seems illogical to regard it as an impediment to the invasiveness of trophoblast when invasiveness is a sine qua non' [28]. McLaren implicitly assumed a conflictual relationship - borders are fortified where the threat of invasion is greatest - whereas cooperative partnership. Such differences of interpretation cannot be resolved or reconciled without an explicit theory of how maternal-fetal relations evolve. No such theory existed until the work of Robert Trivers $[29,30]$.

Trivers defined parental investment as 'any investment by the parent in an individual offspring that increases the offspring's chances of surviving (and hence reproductive success) at the cost of the parent's ability to invest in other offspring. His definition was carefully worded. Parental investment provided a benefit $(B)$ to the offspring at a cost $(C)$ to the parent's fitness from other offspring. If a parental expenditure did not involve such a trade-off, then the expenditure did not qualify as investment [29]. He recognized that parental investment, defined this way, implied an evolutionary conflict between parents and offspring. From a parent's perspective, further investment was favored as long as $B>C$ but, from an offspring's perspective, further investment was favored as long as $B>r C$, where $r$ was a measure of the probability that the parent's other offspring carried a copy of a randomly chosen gene in the offspring. Trivers concluded that genes in offspring are selected to obtain more investment from parents than genes in parents are selected to supply (because $r \leq$ 0.5) [30]. I will attempt to give an intuitive idea of the interplay between cooperation and conflict in maternal-fetal relations with a simple graphical model that elides many theoretical complications.

Consider a plane with two axes (Figure 16.1). One axis represents the effect of a new genetic variant on maternal residual fitness $(\Delta M$, measured as changes in a mother's expected number of surviving offspring not including the fetus). The other axis represents the effect on fetal fitness ( $F$, measured as changes in the fetus' probability of survival). The zero-point, where the axes cross, represents the evolutionary status quo. Points in the upper-right quadrant represent variants that enhance both fetal fitness and maternal residual fitness whereas points in the lower-left quadrant represent variants that reduce both measures. The other two quadrants represent variants that 'rebalance' maternal investment between the two asset classes. In the upper-left quadrant, maternal investment is shifted from the fetus to other offspring, whereas, in the lower-right quadrant, maternal investment is shifted from other offspring to the fetus. (In terms of Trivers' model negative values of $\Delta M$ correspond to a cost to the parent's fitness $(C)$ whereas positive values of $F$ correspond to a benefit to offspring fitness $B$.) 


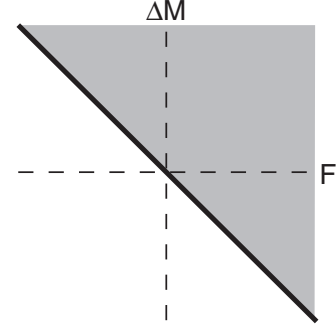

(a) maternal

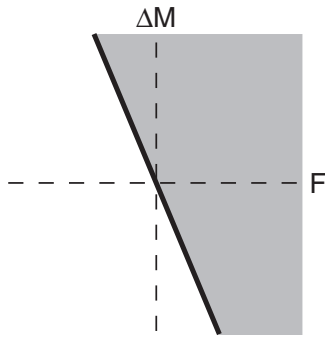

(b) fetal

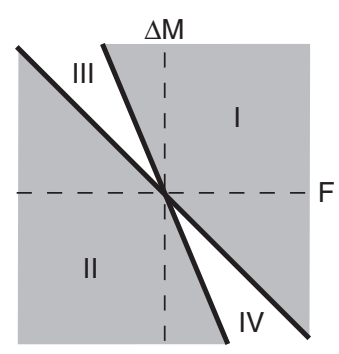

(c) compared
Fig. 16.1 Cooperation and conflict between maternal and fetal genes. $F$ is the change in fetal fitness and $\Delta M$ the change in maternal residual fitness. (A) Maternal inclusive fitness is increased if $F+\Delta M>0$ (shaded area). (B) Fetal inclusive fitness is increased if $F+r M M>0$ (shaded area) where $r$ is the relatedness between two of a mother's offspring. (C) Figures $A$ and $B$ are compared. Maternal and fetal inclusive fitness both benefit in region I and both are reduced in region II. In region III, the mother benefits at the expense of the fetus. In region IV, the fetus benefits at the expense of the mother. These figures were drawn choosing $r=0.5$ to maximize the area of mutual interest (regions I and II). The region of conflict (regions III and IV) expands for smaller r (i.e. lower relatedness among a mother's offspring).
For genes expressed in mothers, natural selection favors changes that satisfy $F+\Delta M>0$ (shaded area of Fig. 16.1A). By contrast, for genes expressed in a fetus, natural selection favors changes that satisfy $F+r \Delta M>$ 0 (shaded area of Fig. 16.1B). The zones of mutual and conflicting interests are visualized in Fig. 16.1C (obtained by combining Fig. 16.1A and Fig. 16.1B). The plane is divided into four regions. In region I, changes are favored independent of whether they are caused by a gene expressed in mothers or fetuses. In region II, changes are disfavored independent of where the gene is expressed. In region III, changes are favored if they are caused by a gene expressed in mothers but not if they are caused by a gene expressed in fetuses (and the reverse in region IV). Thus, regions I and II comprise the zone of maternal-fetal cooperation whereas regions III and IV comprise the zone of maternal-fetal conflict.

There are four points that I wish to make about the foregoing analysis. First, the evolution of maternalfetal relations is complex because a mother and her fetus share some genes, but not all. The genes that are unshared create the opportunity for conflict whereas the genes that are shared restrain the escalation of conflict. Second, there is broad overlap between the interests of maternal and fetal genes. Genetic variants that enhance fetal fitness and maternal residual fitness (upper-right quadrant) will be favored by natural selection regardless of whether they are expressed in the mother or the fetus. Similarly, genetic variants that diminish both fitness measures (lower-left quadrant) will be purged by natural selection regardless of where they are expressed. The interests of maternal and fetal genes may even coincide when a fetus benefits at the cost of other offspring or vice versa (regions I and II extend into the upper-left and lower-right quadrants; Fig. 16.1C). Third, a successful genetic variant establishes a new status quo, around which new genetic variants are selected. Therefore, there will have been a mixture of 'cooperative' and 'antagonistic' gene substitutions in the evolution of any complex feature of maternal-fetal relations. There is no contradiction in the decidua having evolved both as a defensive barrier and as a nurturing environment for the young embryo. Fourth, much of the 'evolutionary action' may take place in the regions of conflict because fetal adaptations to acquire a little bit extra create the selective force for maternal adaptations to supply a little bit less, and so on ad infinitum. This may help to explain the rapid divergence of maternal-fetal relations among taxa, relative to the greater conservatism of physiological relations within individual organisms.

\section{Implantation: a testing time}

'If it is done then when tis done twer better it were done quickly.' -Macbeth

Trivers mentioned the possibility of prenatal conflict between mothers and offspring, but emphasized postnatal conflict [30]. In a series of papers, I have provided the first substantial attempt to apply the theory of parent-offspring conflict to understanding the details of maternal-fetal relations, and I have developed these ideas in a series of subsequent papers $[31,32,33,34,35,36,37]$. An interplay of cooperation and conflict should permeate all aspects of 
maternal-fetal relations, but in the remainder of this chapter I will focus on interactions in the first few weeks after conception.

Many human embryos abort early, often before a woman is aware she has conceived [38]. Moreover, frequent early losses have also been reported in other primates $[39,41]$. Most maternal investment occurs after the first weeks of gestation. Therefore, an early loss can usually be quickly replaced with little cost to a mother's lifetime reproduction. By contrast, continuation of a pregnancy with the birth of a sickly infant can substantially depress a mother's fitness as the child consumes maternal time and resources that could otherwise have been invested in higher-quality sibs. For these reasons, primate mothers are expected to 'test' embryos before commitment of major resources and to be physiologically 'risk-averse' about which embryos are allowed to establish a sustained pregnancy $[42,43]$. The maternal-embryo dialogue may resemble a job interview.

Earlier pregnancy losses have smaller costs for maternal fitness if resources can be redirected to other offspring (reproductive compensation). Natural selection favors the amelioration of deleterious effects in the absence of reproductive compensation but may favor their accentuation if resources can be reallocated. Maternal genes will benefit from the conversion of a small decrement in offspring fitness into a lethal difference if early death is associated with a sufficiently large increase in the fitness of other offspring. For these reasons, reproductive compensation is predicted to favor rigorous testing of early embryos and earlier expression of harmful effects [44,45].

If this were the whole story, one would expect embryonic screening to become ever more effective at increasing offspring quality. However, natural selection acting on genes expressed in embryos will tend to undermine the efficiency of screening because genes of lower-quality embryos have only a chance of their copies being present in higher-quality siblings. Such genes therefore must balance the certainty of a sure bet (investment in their own low-quality offspring) against the chance of a higher return (investment in a high-quality sib). For this reason, natural selection will favor embryos that create a more favorable impression at interview than reflects their true quality.

The complex relations between an examiner (mother) and an examinee (prospective offspring) cannot be pigeon-holed as purely cooperative or purely conflictual. An examiner's aim is to design tests that provide useful information about a candidate as cheaply as possible. The examinee wishes to pass. If the examinee is indeed of high quality, both parties benefit when this information is conveyed accurately, but, if the examinee is of poor quality, her best interest may be to dissemble. The challenge of test design is to ensure a tight correlation between attributes measured and qualities desired. Genes and pathways that are essential for cell survival are automatically, and reliably, tested at the earliest stages of development. But some functions are difficult to test: a mother cannot directly assess neural function in an embryo without neurons; poor visual acuity entails no disadvantage in the darkness of the womb [46; 247].

Any task that an embryo is required to perform tests all genes that are essential for completion of the task. Thus, the necessity for a small embryo to produce large quantities of chorionic gonadotropin (CG) tests not only the genes that encode the hormone's $\alpha$ - and $\beta$ subunits (the latter of little importance in postnatal life) but also the efficient functioning of the machinery of transcription, translation, glycosylation, and cellular secretion. Placental production of a luteinizing hormone (LH), the future CG, may have originated as a form of cheating that allowed embryos to evade maternal mechanisms of pregnancy termination (i.e. withdrawal of pituitary LH). But, the quantity of the placental hormone provided mothers with useable information about embryo quality and was incorporated into the testing procedure as a new requirement for embryos to exceed some threshold level of CG to block regression of the corpus luteum $[31,35]$. Although the original targets of CG were presumably maternal LH receptors of the ovary, CG appears to have acquired additional functions during implantation [47] allowing earlier, less costly, rejection of a subset of embryos.

Examinations select for individuals who are good at passing tests, and discriminate against otherwise equivalent individuals with poorer test performance. For this reason, the correlation between test performance and offspring quality will tend to degrade over evolutionary time as genes that enhance test-taking ability spread through the population. Examiners must add additional tasks or adjust expectations to maintain the usefulness of the testing procedure. For example, the acquisition of extra copies of CG genes and the prolongation of the hormone's half-life [48] would have enhanced an embryo's test performance without changing the resulting offspring's competence 
on tasks that really matter. Mothers are predicted to have responded evolutionarily by increasing the threshold of CG required to maintain pregnancy.

Early human embryos embed themselves within the endometrial stroma (as do the embryos of other apes). By contrast, monkey blastocysts attach to the endometrial surface but remain located within the uterine cavity $[49,50]$. Mossman considered the reasons for the evolution of interstitial implantation to be obscure. Platyrrhine and catarrhine monkeys develop perfectly adequate hemochorial placentae despite superficial implantation of their blastocysts. Therefore, interstitial implantation is not a sine qua non of hemochorial placentation [50; 152-154]. Embedded embryos experience an environment very different from that experienced by superficially attached embryos. It is an open question whether this novel environment created new opportunities for more thorough vetting of offspring.

A typical early pregnancy loss in ancestral primates probably took the form of an attached embryo being flushed out as the uterine lining was shed at the end of the estrous cycle. A superficially attached embryo would be eliminated by sloughing the outermost layer of the endometrium whereas a more deeply embedded embryo would survive. Therefore, interstitial implantation may have originated as an adaptation of embryos to evade this ancestral mechanism of pregnancy termination. Deeper shedding of the endometrium may then have evolved as a maternal countermeasure to re-establish effective testing. Thus, a history of facultative abortion, embryonic evasion of quality control, and maternal responses may help to explain the origin of interstitial implantation and copious menstruation.

The above scenario could be dismissed as no more than a just-so story, incapable of test, because it posits a unique series of unfossilizable events that occurred in an ancestral ape. However, some insight may be obtained from comparative studies of implantation, pregnancy loss, and menstruation in primates. The quantity of maternal tissue shed at menstruation varies markedly among monkeys and apes [51]. Does the depth of menstrual shedding correlate with the depth of implantation? How frequently is menstruation accompanied by an early pregnancy loss?

\section{Schlusskoagulum}

The evolutionary relations between a mother and a fetus are fundamentally similar to the relations between the same two genetic individuals after the birth of the fetus. Mothers care for and nurture their infants but do not accede to each and every demand [52]. And infants have evolved multiple stratagems from charm to blackmail - for eliciting more maternal care. Maternal-fetal relations likewise involve an intricate admixture of cooperation and conflict. Prenatal relations do, however, differ in a couple of important respects from postnatal relations. In the earliest stages of pregnancy, there is little difference between the expected cost to a mother of raising the current embryo or trying again with another embryo. Therefore, mothers abandon early embryos much more readily than they would abandon a child. After an embryo is securely ensconced within the uterus, however, the offspring probably has far greater power to control the delivery of maternal investment than it has at any postnatal stage. The secretion of placental hormones and other factors into maternal blood allows the fetus to treat its mother's body as if it were a direct extension of the fetus's own soma.

\section{Acknowledgments}

Omer Bartov, Richard Bondi, Reimar Brüning, Jan Engelstädter, Karin Michels, Judith Ryan, and Claus Wedekind all provided help with translation from German. The paper has benefited from the insightful comments of Robert Pijnenborg.

\section{References}

1. Gräfenberg E. Beiträge zur Physiologie der Eieinbettung. Z Geburtsh Gynäk 1910; 65: 1-35.

2. Grosser O. Frühentwicklung Eihautbildung und Placentation des Menschen und der Säugetiere. München: JF Bergmann; 1927.

3. Smith W T. The decidua, chorion, placenta, and umbilical cord. Lancet 1856; 1: 171-5.

4. Hunter J. Observations on certain parts of the animal oeconomy. London; 1786.

5. Madge H M. On the anatomical relations between the mother and fotus. Trans Obstet Soc London 1867; 8: 348-60.

6. Hicks J B. The anatomy of the human placenta. Trans Obstet Soc London 1873; 14: 149-207.

7. Reid J. On the anatomical relations of the blood-vessels of the mother to those of the fotus in the human species. Edinburgh Med Surg J 1841; 55: 1-12.

8. Marchand F. Ueber die sogenannten "decidualen" Geschwülste im Anschluss an normale Geburt, Abort, Blasenmole und Extrauterinschwangerschaft. Monatsschr Gerburtsh Gynäk 1895; 1: 419-438, 513-561. 
9. Marchand F. Ueber das maligne Chorion-Epitheliom, nebst Mittheilung von 2 neuen Fällen. Z Geburtsh Gynäk 1898; 49: 173-258.

10. Peters H. Ueber die Einbettung des menschlichen Eies und das früheste bisher bekannte menschliche Placentationsstadium. Leipzig: F Deutike; 1899.

11. Teacher J H. On chorionepithelioma and the occurrence of chorionepitheliomatous and hydatidiform mole-like structures in teratomata. J Obstet Gynoecol Brit Emp 1903; 4: 1-64, 145-199.

12. Fothergill W E. The function of the decidual cell. Edinburgh Med J 1899; 5: 265-73.

13. Frassi L. Über ein junges menschliches Ei in situ. Arch mikroskop Anat Entwicklungsg 1907; 70: 492-505.

14. Polano O. Ueber Verschwinden einer Schwangerschaft. Ein Beitrag zur Lehre von der Blasenmole. $Z$ Geburtsh Gynäk 1907; 59: 453-66.

15. Bryce T H, Teacher J H, Kerr J M M. Contributions to the study of the early development and imbedding of the human ovum. II. An early ovarian pregnancy. Glasgow: J MacLehose; 1908.

16. Ulezko-Stroganova K. Zur Frage von dem feinsten Bau des Deciduagewebes, seiner Histogenese, Bedeutung und dem Orte seiner Entwickelung im Genitalapparat der Frau. Arch Gynaek 1908; 86: 542-63.

17. Grosser O. The development of the egg membranes and the placenta; menstruation. In: Keibel F, Mall F P, eds. Manual of human embryology, Volume 1. Philadelphia: JB Lippincott; 1910; 91-179.

18. Linzenmeier G. Ein junges menschliches Ei in situ. Arch Gynäk 1914; 102: 1-17.

19. Johnstone R W. Contribution to the study of the early human ovum. J Obstet Gynaecol Brit Emp 1914; 25: 231-76.

20. Caffier P. Die proteolytische Fähigkeit von Ei und Eibett. (Experimentelle Studien mit Chorion und Decidua). Zentralb Gynäk 1929; 53: 2410-25.

21. Caffier P. Zur Biologie von Ei und Eibett. Klin Wochenschr 1932; 11: 1089-92.

22. Kleine H O. Zur Systematik der Pathologie der sog. Durchdringungszone. Arch Gynäk 1931; 145: 459-73.

23. Arey L B. Placentation, fetal membranes and deciduae. In: Curtis A H, ed. Obstetrics and gynecology. Philadelphia: WB Saunders; 1933: 442-76.

24. Mossman H W. Comparative morphogenesis of the fetal membranes and accessory uterine structures. Contrib Embryol 1937; 26: 129-246.

25. Bonnet M. Ueber Syncytien, Plasmodien und Symplasma in der Placenta der Säugetiere und des
26. Ritter F. Über Deciduazellen und ihre Bedeutung. Beitr Geburtsh Gynäk 1910; 15: 226-41.

27. McLaren A. Maternal factors in nidation. In: Park $\mathrm{W} \mathrm{W}$, ed. The early conceptus, normal and abnormal. St. Andrews: University of St. Andrews; 1965: pp. 27-33.

28. Robertson W B, Warner B. The ultrastructure of the human placental bed. J Pathol 1974; 112: 203-11.

29. Trivers R L. Parental investment and sexual selection. In: Campbell B, ed. Sexual selection and the descent of man, 1871-1971. Chicago: Aldine Publishing; 1972: 136-79.

30. Trivers R L. Parent-offspring conflict. Amer Zool 1974; 14: 249-64.

31. Haig D. Genetic conflicts in human pregnancy. Q Rev Biol 1993; 68: 495-532.

32. Haig D. Gestational drive and the green-bearded placenta. Proc Natl Acad Sci USA 1996; 93: 6547-51.

33. Haig D. Placental hormones, genomic imprinting, and maternal-fetal communication. J Evol Biol 1996; 9: 357-80.

34. Haig D. Altercation of generations: genetic conflicts of pregnancy. Amer J Reprod Immunol 1996; 35: 226-32.

35. Haig D. Genetic conflicts of pregnancy and childhood. In: Stearns S C, ed. Evolution in health and disease. Oxford: Oxford University Press; 1999; 77-90.

36. Haig D. Evolutionary conflicts in pregnancy and calcium metabolism: a review. Placenta 2004; 25 (Suppl A): S10-S15.

37. Haig D. Putting up resistance: maternal-fetal conflict over the control of uteroplacental blood flow. In: Aird W C, ed. Endothelial biomedicine. Cambridge: Cambridge University Press; 2007: 135-41.

38. Wilcox A J, Weinberg C R, O’Connor J F et al. Incidence of early loss of pregnancy. New Engl J Med 1988; 319 : 189-94.

39. Small M F. Reproductive failure in macaques. Amer J Primatol 1982; 2: 137-47.

40. Kuehl T J, Kang I S, Siler-Khodr T M. Pregnancy and early reproductive failure in the baboon. Amer J Primatol 1992; 28: 41-8.

41. Hobson W C, Graham C E, Rowell T J. National Chimpanzee Breeding Program: Primate Research Institute. Amer J Primatol 1991; 24: 257-63.

42. Kozlowski J, Stearns S C. Hypotheses for the production of excess zygotes: models of bet-hedging and selective abortion. Evolution 1989; 43: 1369-77.

43. Haig D. Brood reduction and optimal parental investment when offspring differ in quality. Amer Nat 1990; 136: 550-6. 
44. Hamilton W D. The moulding of senescence by natural selection. J Theor Biol 1966; 12: 12-45.

45. Hastings I M. Models of human genetic disease: how biased are the standard formulae? Genet Res 2000; 75: 107-114.

46. Ridley M. Mendel's demon. London: Weidenfeld \& Nicolson; 2000.

47. Licht $\mathrm{P}$, Fluhr $\mathrm{H}$, Neuwinger J et al. Is human chorionic gonadotropin directly involved in the regulation of human implantation? Mol Cell Endocrinol 2007; 269: 85-92.
48. Henke A, Gromoll J. New insights into the evolution of chorionic gonadotropin. Mol Cell Endocrinol 2008; 291 : 11-19.

49. Wislocki G B. On the placentation of primates, with a consideration of the phylogeny of the placenta. Contrib Embryol 1929; 20: 51-80.

50. Mossman H W. Vertebrate fetal membranes. New Brunswick: Rutgers University Press; 1987.

51. Strassmann B I. The evolution of endometrial cycles and menstruation. Q Rev Biol 1996; 71: 181-220.

52. Hrdy S B. Mother nature. New York: Pantheon; 1999. 